\title{
La guerra de la Independencia : una nueva historia
}

\author{
Marta Ruiz Jimenez
}

\section{(2) OpenEdition}

Journals

Édition électronique

URL : https://journals.openedition.org/ahrf/1749

DOI : 10.4000/ahrf.1749

ISSN : 1952-403X

Éditeur :

Armand Colin, Société des études robespierristes

Édition imprimée

Date de publication : 1 juin 2004

Pagination : 240

ISSN : 0003-4436

Référence électronique

Marta Ruiz Jimenez, "La guerra de la Independencia : una nueva historia », Annales historiques de la Révolution française [En ligne], 336 | avril-juin 2004, mis en ligne le 20 février 2006, consulté le 23 avril 2022. URL : http://journals.openedition.org/ahrf/1749 ; DOI : https://doi.org/10.4000/ahrf.1749

Ce document a été généré automatiquement le 23 avril 2022.

Tous droits réservés 


\title{
La guerra de la Independencia : una nueva historia
}

\author{
Marta Ruiz Jimenez
}




\section{RÉFÉRENCE}

Charles Esdaile, La guerra de la Independencia : una nueva historia, Barcelona, ed. Crítica, 2003, 647 p., ISBN 84-8432-475-3, 35.90€.

1 Ce livre reconstruit l'histoire de la Guerre de l'Indépendance espagnole (1808-1814) dans le but de proposer de nouvelles perspectives d'interprétation. En ce sens, l'auteur ne veut pas nous apporter une simple synthèse et il s'éloigne de la description simplement militaire : il prend en compte les aspects politiques et sociaux du conflit et nous offre aussi un répertoire bibliographique commenté.

Il s'agit ici d'un livre polémique, où l'auteur - qui a écrit d'autres œuvres d'histoire militaire et sur le XIXe siècle espagnol - discute certaines affirmations sur le conflit et sur la nature de la guérilla, affirmations jusqu'à présent estimées incontestables. Toutefois, l'auteur, qui considère surtout l'aspect militaire, subordonne d'autres aspects d'ordre politique, économique et social à ceux d'ordre guerrier. Et de ce fait, Charles Esdaile soutient des conclusions peut-être très risquées en attribuant aux partisans espagnols des motivations appuyées sur le " pillage», «l'extorsion » et « les assauts dans les chemins ", motivations très éloignées d'un présumé patriotisme.

D'ailleurs, Charles Esdaile pense que la Guerre de l'Indépendance n'a pas été un facteur majeur dans le développement des guerres napoléoniennes. C'est pour cela qu'il nie que ce conflit ait eu un poids important sur la défaite de l'empire napoléonien. Néanmoins, le conflit a laissé une forte empreinte dans le devenir de l'histoire de l'Espagne, où - en plus de toutes les fatales conséquences humaines et économiques que toute guerre comporte - il a été à l'origine de deux facteurs qui ont caractérisé l'Espagne du XIXe siècle : la guerre civile et l'intrusion de l'armée dans la politique. 